University of Nebraska - Lincoln

DigitalCommons@University of Nebraska - Lincoln

USDA National Wildlife Research Center - Staff Publications
U.S. Department of Agriculture: Animal and Plant Health Inspection Service

2010

\title{
Superabundant Food at Catfish Aquaculture Facilities Improves Body Condition in American White Pelicans
}

\author{
D. Tommy King \\ USDA/APHIS/WS National Wildlife Research Center, tommy.king@aphis.usda.gov \\ Jerold Belant \\ Mississippi State University \\ Brent Harrel \\ United States Department of Agriculture \\ James Glahn \\ United States Department of Agriculture
}

Follow this and additional works at: https://digitalcommons.unl.edu/icwdm_usdanwrc

King, D. Tommy; Belant, Jerold; Harrel, Brent; and Glahn, James, "Superabundant Food at Catfish Aquaculture Facilities Improves Body Condition in American White Pelicans" (2010). USDA National Wildlife Research Center - Staff Publications. 1271.

https://digitalcommons.unl.edu/icwdm_usdanwrc/1271

This Article is brought to you for free and open access by the U.S. Department of Agriculture: Animal and Plant Health Inspection Service at DigitalCommons@University of Nebraska - Lincoln. It has been accepted for inclusion in USDA National Wildlife Research Center - Staff Publications by an authorized administrator of DigitalCommons@University of Nebraska - Lincoln. 


\title{
Superabundant Food at Catfish Aquaculture Facilities Improves Body Condition in American White Pelicans
}

\author{
D. TOMmY KinG ${ }^{1, *}$, Jerold Belant ${ }^{2}$, BRENT HARREL $^{1,3}$ AND JAMES GLAhN ${ }^{1,4}$ \\ ${ }^{1}$ United States Department of Agriculture, Wildlife Services, National Wildlife Research Center, Mississippi State, \\ MS, 39762, USA \\ ${ }^{2}$ Carnivore Ecology Laboratory, Forest and Wildlife Research Center, Mississippi State University, Mississippi State, \\ MS, 39762, USA \\ ${ }^{3}$ Current address: United States Department of Interior, Fish and Wildlife Service, Kentucky Ecological Services \\ Field Office, 3761 Georgetown Rd., Frankfort, KY, 40601, USA \\ ${ }^{4}$ Current address: P.O. Box 532, Jamestown, KY, 4269, USA \\ "Corresponding author; E-mail: Tommy.King@aphis.usda.gov
}

\begin{abstract}
Few studies have investigated the use of aquaculture-produced foods by piscivorous birds. American White Pelicans (Pelecanus erythrorhynchos) were collected from four locations (two aquaculture, one riverine and one coastal) in the southeastern United States during winter and spring 1998-1999 to assess the contribution (biomass, frequency of occurrence) of aquaculture-produced foods and their effect on body condition. Pelican diets reflected opportunistic foraging across locations. Diet near catfish ponds consisted mostly of Channel Catfish (Ictalurus punctatus). Diets along the Mississippi River had similarly high biomass of catfish, but otolith counts suggested lower use of catfish. Diets near crawfish (Procambarus spp.) ponds included shad (Dorsomis spp.), crawfish and sunfish (Lepomis spp.); whereas diets from coastal Louisiana were predominantly salt water fish. Pelican body condition, as indexed by percent omental fat, was similar between seasons but higher at catfish ponds. Foraging at crawfish ponds did not improve body condition over foraging in natural conditions. The superabundant, large and vulnerable food source (i.e. catfish in aquaculture ponds) likely resulted in reduced energy expenditures by pelicans, which would improve body condition. Higher fat reserves could facilitate spring migration and reproductive success. American White Pelican use of catfish at aquaculture facilities is predicted to continue and likely increase. Received 22 July 2009, accepted 8 October 2009.
\end{abstract}

Key words.-American White Pelican, aquaculture, body condition, Channel Catfish, diet, Ictalurus, Pelecanus erythrorhynchos, southeastern United States.

Waterbirds 33(2): 221-227, 2010

Wildlife use of superabundant food occurs when the food in question is much more abundant than the requirements of the consumers, even if the food comprises most of the diet of the species involved (Lack 1946). Wildlife use of some agricultural commodities have been widely documented and publicized. For example, white-tailed deer (Odocoileus virginianus) and blackbirds commonly depredate agricultural crops (Conover 1994; Linz et al. 2003). These superabundant food sources are often credited with enhancing survival and reproductive fitness (Glahn et al. 2000). Until recently, the potential benefit to wildlife foraging on commercial aquaculture has received little attention.

Commercial aquaculture production in the southeastern United States has grown dramatically during the past 25 years. For ex- ample, the number of hectares of commercial catfish (Ictalurus punctatus) production in the southeastern United States (Alabama, Arkansas, Louisiana and Mississippi) increased from 28,000 ha to 61,000 ha from 1987 to 2007 (USDA 2008). Concurrent to this increase in production area has been an increase in the numbers of piscivorous birds foraging at aquaculture facilities (Stickley and Andrews 1989; Fleury 1993; King and Werner 2001; Glahn and King 2004). Double-crested Cormorants (Phalacrocorax auritus) have been regarded as the major depredating species in the southeastern United States, particularly at commercial catfish ponds (Wywialowski 1999; Glahn and King 2004).

Similar to Double-crested Cormorants, use of aquaculture facilities by American 
White Pelicans (Pelecanus erythrorhynchos) has increased during the last 20 years (King 1997; King 2005). Pelican foraging at commercial ponds was first reported during the 1990s (King 1997). More recently, flocks of $>2000$ pelicans have been observed foraging on commercial catfish ponds, as well as at commercial crawfish (Procambarus spp.) ponds in southern Louisiana (King 1997; King and Michot 2002; King 2005). American White Pelicans also come in conflict with southeastern aquaculture by using this superabundant and readily available food source (King 1997; King 2005).

Cormorant exploitation of aquaculture may lead to increased survival and enhanced productivity (Weseloh and Ewins 1994; Duffy 1995). Glahn et al. (2000) found that wintering Double-crested Cormorants collected in the intensive aquaculture region of Mississippi and foraging on catfish had significantly higher levels of fat than cormorants collected in eastern Alabama (a non-aquaculture region). The improved body condition led Glahn et al. (2000) to suggest that cormorants exploiting catfish aquaculture increased their survival and contributed to cormorant population increases. We hypothesize that the same might be true for American White Pelicans.

The goal of this research was to provide insight on the effects of catfish exploitation at aquaculture facilities on the body condition of American White Pelicans. The study objectives were to: 1 ) estimate if pelican diet reflects use of nearby foraging resources, including aquaculture facilities and 2) determine if use of superabundant food resources at aquaculture facilities improved pelican body condition, as indexed by body fat.

\section{METHODS}

\section{Study Area}

American White Pelicans were collected from loafing sites (King 1997; King and Werner 2001; King and Michot 2002; King 2005) during winter (December 1998, January-February 1999) and spring (March 1999 and April 1998, 1999) at four geographic regions in Mississippi and Louisiana (Fig. 1). King and Werner (2001) found that in intensive aquaculture areas, pelicans typically forage near their loafing sites. The Mississippi aquaculture pond location included two collection sites

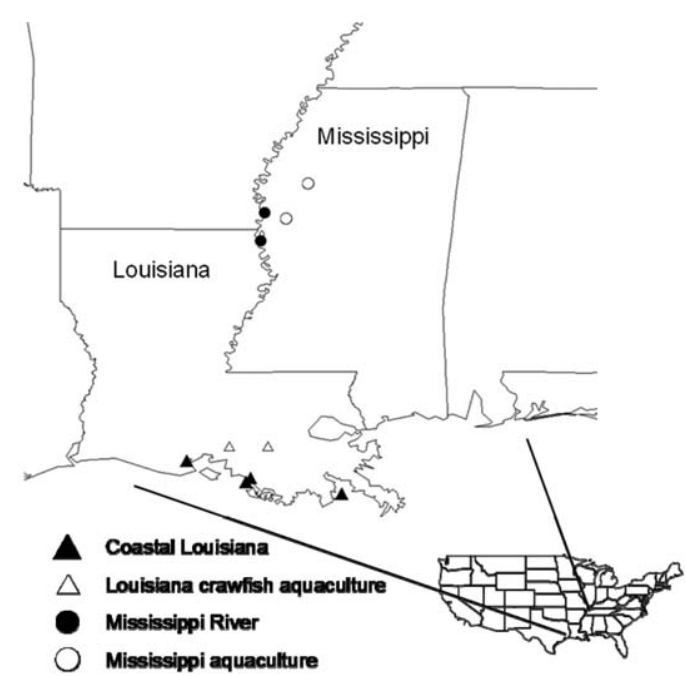

Figure 1. Location of study areas for estimating American White Pelican diet from the southeastern United States, December-April 1998-1999.

$<1.6 \mathrm{~km}$ from catfish aquaculture facilities in LeFlore and Washington Counties, Mississippi. The Mississippi River location included two sites; a mud flat in the Mississippi River and an oxbow lake inside the Mississippi River levee in Issaquena and Washington counties, Mississippi. The Mississippi River collection location was $\geq 30 \mathrm{~km}$ from the nearest catfish aquaculture facility. The Louisiana crawfish location consisted of two collection sites $<3 \mathrm{~km}$ from crawfish aquaculture facilities in Assumption and St. Mary Parishes, Louisiana. The Coastal Louisiana location included three sites within marsh habitat in Jefferson, St. Mary and Vermillion Parishes, Louisiana. Coastal Louisiana collection sites were $>40 \mathrm{~km}$ from the nearest crawfish aquaculture ponds.

Catfish aquaculture ponds in Mississippi average 6 ha in size and are about $1.5 \mathrm{~m}$ deep. Recommended catfish fingerling stocking rates are about 20,000 fish/ha but may vary widely depending on the culture method employed (Tucker et al. 2004). In Mississippi, the most common culture method involves multiple age classes of fish being grown in a single pond (Tucker et al. 2004). The method provides a continuum of fish sizes, ranging from recently stocked fingerlings $(16 \mathrm{~g}$ and $13 \mathrm{~cm})$ to food size fish $(>1.5 \mathrm{~kg}$ and $50 \mathrm{~cm})$, and provides harvestable fish on a near constant basis (Tucker et al. 2004). Shad (Dorsomis spp.) and sunfish (Lepomis spp.) are endemic to most freshwater areas in the southeastern United States and these fishes are often found in commercial aquaculture ponds due to flooding overflow into fish ponds or transported by wildlife (J. Avery, National Warmwater Aquaculture Center, personal communication).

Field and Laboratory Methods

American White Pelicans were collected from loafing areas using shotguns or center-fire rifles. The age of each bird was determined using external plumage characteristics and other morphological features (Johnsgard 1993; Knopf and Evans 2004); sex was determined 
by examination of reproductive organs. The esophagus, stomach and lower gastro-intestinal tract was removed as soon as possible from each bird, stored on ice in a labeled plastic bag, and transported to the National Wildlife Research Center Mississippi Field Station, Starkville, Mississippi. All procedures involving American White Pelicans were conducted under an IACUC-approved United States Department of Agriculture, Wildlife Services, National Wildlife Research Center study protocol (QA-577), a Louisiana Department of Wildlife and Fisheries Scientific Collecting Permit, a Mississippi Department of Wildlife, Fisheries and Parks Administrative Scientific Collecting Permit and a United States Department of Interior Scientific Collecting Permit.

Stomach contents were removed and all prey items were identified, measured and weighed to the nearest gram following procedures in Glahn et al. (1995; 1998; $2000)$. Teleost otoliths were retained for prey identification and to increase species composition (Harrel and Stringer 1996; Derby and Lovvorn 1997; Glahn et $a l .1998)$. Otoliths were used to identify fish prey items to family and genus using methods described in Glahn et al. (1998). No attempt was made to determine fish length or age using otoliths due to possible erosion of otoliths (Johnstone et al. 1990). Omental fat was scraped from the stomach exterior, placed in a plastic weighing dish, and weighed to the nearest gram (Glahn et al. 2000).

\section{Statistical Analyses}

The biomass of each whole fish and crawfish found in pelican gastro-intestinal tracts was estimated based on length-to-weight equations (Kohler and Hubert 1993; Glahn et al. 1995; Murphy and Willis 1996). These food items were grouped into five categories of dominant prey types (catfish, shad, crawfish, sunfish and other fish). Data were too sparse to consider both spatial and temporal comparisons or among age and gender of birds. To compare prey size the mean length of the most frequently occurring prey (i.e. catfish) was compared with the mean length of all other prey species combined using a $t$-test.

Fish otoliths from the stomachs of fish-eating birds can provide useful dietary information (Glahn et al. 1998), therefore the percent by number of otoliths found in pelicans across the four collection locations were grouped into the following categories and compared: catfish, shad, sunfish and other fish (including a wide variety of primarily salt water fish families and genera). Omental fat was expressed as a percentage of total body weight. A general linear model analysis of variance (PROC GLM; SAS 1989) with least significant difference multiple range test was used to compare mean per- cent omental fat between seasons (winter, spring) and across the four geographic locations. Limited sample sizes precluded analyses by sex or age class. Statistical tests were considered to be significant at $P \leq 0.05$ and reported means are $\pm \mathrm{SD}$.

\section{RESULTS}

A total of 187 American White Pelicans were collected, 86 during winter and 101 during spring. Fifty-seven pelicans were collected from Mississippi catfish ponds (20 in winter, 37 in spring), 49 pelicans from the Mississippi River (20 in winter, 29 in spring), 42 pelicans from Louisiana crawfish ponds (24 in winter, 18 in spring), and 39 birds from coastal Louisiana (22 in winter, 17 in spring).

Catfish represented $>99 \%$ of whole fish biomass consumed by pelicans in all areas of Mississippi, with comparable biomass between pelicans from catfish ponds and the Mississippi River (Table 1). Maximum estimated catfish biomass collected from a single pelican was $3.1 \mathrm{~kg}$. Shad represented the greatest percentage of prey biomass $(32.8 \%)$ in pelicans from Louisiana crawfish ponds, followed by crawfish and sunfish. Coastal Louisiana pelicans consumed primarily saltwater fish. Estimated mean length of catfish consumed by pelicans $(267 \pm 113 \mathrm{~mm}, \mathrm{~N}=$ $81)$ was 4.5 times greater $(t=15.82,92 \mathrm{df}, P$ $<0.001)$ than the estimated mean length of other fish consumed $(60 \pm 43 \mathrm{~mm}, \mathrm{~N}=160)$ by pelicans.

Based on otoliths, pelicans at Mississippi catfish ponds consumed at least three times more catfish than did pelicans at other locations (Table 2). The difference in the number of shad represented in whole prey and otoliths may be due to shad being generally

Table 1. Percent biomass of prey items in gastrointestinal tracts of American White Pelicans from the southeastern United States, December-April 1998-1999. ( $\mathrm{N}=$ number of whole prey).

\begin{tabular}{|c|c|c|c|c|c|c|}
\hline \multirow[b]{2}{*}{ Location } & \multicolumn{6}{|c|}{ Prey item } \\
\hline & $\mathrm{N}$ & Catfish & Shad & Crawfish & Sunfish & Other \\
\hline Mississippi catfish ponds & 28 & 99.6 & 0.4 & 0.0 & 0.0 & 0.0 \\
\hline Mississippi River & 15 & 99.2 & 0.8 & 0.0 & 0.0 & 0.0 \\
\hline Louisiana crawfish ponds & 16 & 6.8 & 32.8 & 23.7 & 20.2 & 16.6 \\
\hline Coastal Louisiana & 10 & 1.0 & 0.0 & 0.0 & 0.0 & 99.0 \\
\hline
\end{tabular}


Table 2. Percent of teleost otoliths in gastrointestinal tracts of American White Pelicans from the southeastern United States, December-April 1998-1999. ( $\mathrm{N}=$ number of otoliths).

\begin{tabular}{lrrrrr}
\hline \hline & \multicolumn{5}{c}{ Prey item (\%) } \\
\cline { 2 - 6 } Location & \multicolumn{1}{c}{$\mathrm{N}$} & Catfish & Shad & Sunfish & Other \\
\hline Mississippi catfish ponds & 153 & 87.6 & 8.5 & 2.0 & 2.0 \\
Mississippi River & 222 & 29.7 & 58.6 & 6.3 & 5.4 \\
Louisiana crawfish ponds & 1,241 & 0.5 & 63.3 & 27.6 & 8.7 \\
Coastal Louisiana & 243 & 1.2 & 7.4 & 12.8 & 78.6 \\
\hline
\end{tabular}

smaller and easier to digest than catfish. Shad represented the majority of fish consumed by pelicans along the Mississippi River and at Louisiana crawfish ponds. As with whole prey examined, otoliths collected from coastal Louisiana pelicans were primarily from saltwater fishes.

Mean percent omental fat in pelicans varied across study locations $(F=18.85 ; 3,183 \mathrm{df} ; P$ $<0.001)$, with overall highest $(P<0.05)$ fat levels occurring in pelicans collected from catfish ponds in Mississippi (Table 3). Mean percent omental fat in pelicans collected from the Mississippi River and coastal Louisiana was similar $(P>0.05)$ and both were greater than the mean percent omental fat in pelicans from Louisiana aquaculture facilities $(P<0.05)$.

For all locations combined, percent omental fat was similar $(F=2.93 ; 1,185 \mathrm{df} ; P$ $=0.089$ ) between winter and spring. There was an interaction, however, between season and collection location $(F=36.01 ; 3,183 \mathrm{df}$; $P<0.001$ ), with omental fat increasing from winter to spring in pelicans collected only at Mississippi catfish ponds.

\section{DISCUSSION}

American White Pelicans are generally described as opportunistic shallow water for- agers that use a variety of aquatic habitats (Johnsgard 1993; King and Werner 2001; King and Michot 2002; Knopf and Evans 2004). Our study documents the widespread use of both catfish and crawfish aquaculture facilities by pelicans. Previous studies have shown that American White Pelicans use southeastern catfish ponds while staging for spring migration (King and Werner 2001; King and Grewe 2001; King and Michot 2002). Pelicans are more prevalent on catfish ponds during spring and are tenacious foragers, making them hard to disperse from ponds and nearby loafing sites (King and Michot 2002; King 2005). The sizes of catfish found in pelican stomachs were comparable to the sizes of fish typically found in catfish aquaculture ponds. Further, the majority of channel catfish consumed by pelicans collected at aquaculture and river sites in Mississippi were commercially raised because undigested portions of corn kernels were found in the pelican stomachs. Commercial catfish feeds often utilize corn as an energy supplement (Robinson et al. 2004).

Pelicans loafing along the Mississippi River also foraged on catfish, potentially from natural water bodies and/or from aquaculture ponds. Pelicans do forage in natural areas (King and Werner 2001; King and Mi-

Table 3. Mean (SD) percent omental fat in American White Pelicans from the southeastern United States during winter (Dec-Feb) and spring, (Mar-Apr), 1998-1999. Means within a row with different letters are significantly different $(P<0.05)$.

\begin{tabular}{|c|c|c|c|c|c|c|}
\hline \multirow[b]{2}{*}{ Location } & \multicolumn{3}{|c|}{ Winter } & \multicolumn{3}{|c|}{ Spring } \\
\hline & $\mathrm{N}$ & $\overline{\mathrm{x}}$ & $\mathrm{SD}$ & $\mathrm{N}$ & $\overline{\mathrm{x}}$ & SD \\
\hline Mississippi catfish ponds & 20 & $0.81^{\mathrm{a}}$ & 0.35 & 37 & $3.15^{\mathrm{b}}$ & 1.44 \\
\hline Mississippi River & 20 & $2.58^{\mathrm{a}}$ & 1.14 & 29 & $1.05^{\mathrm{a}}$ & 0.49 \\
\hline Louisiana crawfish ponds & 24 & $1.07^{\mathrm{a}}$ & 0.81 & 18 & $0.45^{\mathrm{a}}$ & 0.25 \\
\hline Coastal Louisiana & 22 & $1.31^{\mathrm{a}}$ & 1.03 & 17 & $1.86^{\mathrm{a}}$ & 1.22 \\
\hline
\end{tabular}


chot 2002), coming in contact with shad and other endemic prey species. This study documented that coastal Louisiana birds foraged almost exclusively on naturally-occurring brackish and saltwater species.

Pelicans foraging on catfish during spring (presumably from catfish ponds) were in better physical condition than birds not exploiting catfish aquaculture. Typical catfish aquaculture ponds appear to provide a near-perfect foraging environment for American White Pelicans (King 2005), as the relatively small and shallow ponds assure that the fish are confined and vulnerable to foraging pelicans. In addition, stocking densities of catfish at aquaculture facilities far exceed fish densities observed in natural water bodies. Consequently, pelicans foraging in catfish ponds spend less time per day foraging than birds foraging in natural areas (King and Werner 2001). Thus, pelicans foraging on superabundant commercial catfish can meet their energetic demands with less effort, leading to higher body fat content and better overall body condition. Pelicans are capable of traveling long distances to reach foraging sites (Knopf and Evans 2004). Although pelicans loafing along the Mississippi River exploited commercial catfish, the increased energy expended by flying $\geq 30 \mathrm{~km}$ to reach the ponds may have resulted in lower mean percent levels of omental fat.

Percent body fat of American White Pelicans foraging in commercial crawfish ponds was lower than for pelicans foraging elsewhere. Although crawfish in commercial aquaculture ponds were abundant, they were likely more difficult to capture in adequate quantities and were undoubtedly less digestible than fish due to their exoskeleton. Therefore, pelicans exploiting crawfish ponds did not benefit from enhanced body condition as pelicans exploiting catfish ponds.

These data show that pelicans foraging at catfish aquaculture facilities, particularly during spring, are in better physical condition (as indexed by percent body fat) than pelicans that forage at alternate locations. Increased body fat has been positively associ- ated with migratory and reproductive success in birds (Ankney and MacInnes 1978; Moore et al. 1995); consequently pelicans foraging at catfish aquaculture are likely in better condition for spring migration to breeding grounds. Increased condition could also improve reproductive performance and survival (Rogers 1987; Rowe et al. 1994), resulting in potential population increases for this species. A similar avian response to foraging at catfish aquaculture facilities has been reported for Double-crested Cormorants (Hatch and Weseloh 1999; Glahn et al. 2000).

\section{Management Implications}

These data, combined with previous research, suggest American White Pelican exploitation of the superabundant food provided by catfish aquaculture will likely continue and possibly increase. Exploitation of catfish aquaculture has been credited with causing a shift in the winter range of Doublecrested Cormorants (Weseloh and Ewins 1994). Similarly, King and Grewe (2001) described an apparent shift in American White Pelican wintering ranges associated with increased catfish aquaculture. Improved body condition resulting from exploitation of catfish aquaculture may result in higher survival and improved reproductive performance of American White Pelicans. The use of catfish aquaculture by pelicans will likely continue and as more pelicans learn to exploit catfish aquaculture, conflicts with producers will likely increase. Management strategies to reduce pelican predation should focus on deterring pelican foraging at catfish aquaculture facilities, especially during spring.

\section{ACKNOWLEDGMENTS}

The authors thank B. S. Dorr, G. Ellis, A. Gaudé, D. LeBlanc, the Louisiana Department of Wildlife and Fisheries and numerous land owners for assistance with pelican collections. S. Curran, P. Fioranelli, J. Hackathorn, S. McNamara and S. Tipton, provided laboratory assistance. S. Curran, S. Harrel, M. Peterson and G. L. Stringer assisted with otolith identification. P. Gerard provided statistical advice. We thank J. Eisemann, B. Washburn, G. Witmer and two anonymous reviewers for comments on the manuscript. 


\section{LITERATURE CITED}

Ankney, C. D. and C. D. MacInnes. 1978. Nutrient reserves and reproductive performance of female Lesser Snow Geese. Auk 95: 459-471.

Conover, M. R. 1994. Perceptions of grass-roots leaders of the agricultural community about wildlife damage on their farms and ranches. Wildlife Society Bulletin 22: 94-100.

Derby, C. E. and J. R. Lovvorn. 1997. Comparison of pellets versus collected birds for sampling diets of Double-crested Cormorants. Condor 99: 549-553.

Duffy, D. C. 1995. Why is the Double-crested Cormorant a problem? Insights from cormorant ecology and human ecology. Colonial Waterbirds 18 (Special Publication 1): 25-32.

Fleury, B. E. 1993. Population trends in Louisiana herons, egrets, and ibises from 1949 to 1989. In Management of fish eating birds on fish farms: a symposium (J. V. Huner, Ed.),. National Aquaculture Association and National Audubon Society, 5-6 January 1993, New Orleans, Louisiana.

Glahn, J. F., P. J. Dixon, G. A. Littauer and R. B. McCoy. 1995. Food habits of Double-crested Cormorants wintering in the delta region of Mississippi. Colonial Waterbirds 18 (Special Publication 1): 158-167.

Glahn, J. F., J. B. Harrel and C. Vyles. 1998. The diet of wintering Double-crested Cormorants feeding at lakes in the southeastern United States. Colonial Waterbirds 21: 431-437.

Glahn, J. F., M. E. Tobin and J. B. Harrel. 2000. Possible effects of catfish exploitation on overwinter body condition of Double-crested Cormorants. Pages 107113 In Symposium on Double-crested Cormorants: population status and management issues in the Midwest (M. E. Tobin, Ed.). APHIS Technical Bulletin No. 1879. United States Department of Agriculture, Milwaukee, Wisconsin.

Glahn, J. F. and D. T. King. 2004. Bird Depredation. Pages 503-529 In Biology and Culture of Channel Catfish. Developments in Aquaculture and Fisheries Science-34 (C. S. Tucker and J. A. Hargreaves, Eds.). Elsevier, Amsterdam, Netherlands.

Harrel, J. B. and G. L. Stringer. 1997. Feeding habits of the Alligator Snapping Turtle (Macroclemys temminckii) as indicated by teleostean otoliths. Herpetological Review 28: 185-187.

Hatch, J. J. and D. V. Weseloh. 1999. Double-crested Cormorant (Phalacrocorax auritus). The Birds of North America Online (A. Poole, Ed.). Ithaca: Cornell Lab of Ornithology. <http://bna.birds.cornell.edu/bna/species/441doi:10.2173/bna.441>. Accessed 10 September 2008.

Johnsgard, P. A. 1993. Cormorants, darters, and pelicans of the world. Smithsonian Institution, Washington, D.C.

Johnstone, I. G., M. P. Harris, S. Wanless and J. A. Graves. 1990. The usefulness of pellets for assessing the diet of adult Shags Phalacrocorax aristolelis. Bird Study 37: 5-11.

King, D. T. 1997. American White Pelicans: The latest avian problem for catfish producers. Proceedings of the Vertebrate Pest Conference 7: 31-35.

King, D. T. and A. H. Grewe, Jr. 2001. Movements and mortality of American White Pelicans banded at Marsh Lake, Minnesota. North American Bird Bander 26: 57-60.
King, D. T. and S. J. Werner. 2001. Daily activity budgets and population size of American White Pelicans wintering in south Louisiana and the delta region of Mississippi. Waterbirds 24: 250-254.

King, D. T. and T. C. Michot. 2002. Distribution, abundance, and habitat use of American White Pelicans in the delta region of Mississippi and along the western Gulf of Mexico coast. Waterbirds 25: 410416.

King, D. T. 2005. Interactions between American White Pelicans and commercial aquaculture in the southeastern United States: an overview. In Biology and Conservation of the American White Pelican (D. W. Anderson, D. T. King and J. Coulson, Eds.). Waterbirds 28 (Special Publication 1): 83-86.

Knopf, F. L. and R. M. Evans. 2004. American White Pelican (Pelecanus erythrorhynchos), The Birds of North America Online (A. Poole, Ed.). Ithaca: Cornell Lab of Ornithology. <http://bna.birds.cornell.edu/ bna/species/057doi:10.2173/bna.57>. Accessed 10 September 2008.

Kohler, C. C. and W. A. Hubert, Editors. 1993. Inland fisheries management in North America. American Fisheries Society, Bethesda, Maryland.

Lack, D. 1946. Competition for food by birds of prey. Journal of Animal Ecology 15: 123-129.

Linz, G. M., H. J. Homan, L. B. Penry and P. Mastrangelo. 2003. Reducing blackbird-human conflicts in agriculture and feedlots: new methods for an integrated management approach. Pages 21-24 In Management of North American Blackbirds (G. M. Linz, Ed.). National Wildlife Research Center, Fort Collins, Colorado.

Moore, F. R., S. A. Gauthreaux, P. Kerlinger and T. R. Simons. 1995. Habitat requirements of during migration: important link in Conservation. Pages 121-144 In Ecology and management of Neotropical migratory birds: a synthesis and review of critical issues ( $\mathrm{T}$. E. Martin and D. M. Finch, Eds.). Oxford University Press, New York, New York.

Murphy, B. R. and D. W. Willis. 1996. Fisheries techniques. Second Edition. American Fisheries Society, Bethesda, Maryland.

Robinson, E. H., B. B. Manning and M. H. Li. 2004. Feeds and feeding practices. Pages 324-348 in Biology and culture of channel catfish. Developments in Aquaculture and Fisheries Science-34 (C. S. Tucker and J. A. Hargreaves, Eds.). Elsevier. Amsterdam, Netherlands.

Rogers, C. M. 1987. Predation risk and fasting capacity: do wintering birds maintain optimal body mass? Ecology 68: 1051-1061.

Rowe, L., D. Ludwig and D. Schluter. 1994. Time, condition, and the seasonal decline of avian clutch size. American Naturalist 143: 698-722.

SAS Institute, Inc. 1989. SAS/STAT® User's Guide, Version 6, Fourth Edition, Volume 2, Cary, North Carolina.

Stickley, A. R., Jr. and K. J. Andrews. 1989. Survey of Mississippi catfish farmers on means, effort, and costs to repel fish-eating birds from ponds. Proceedings of the Eastern Wildlife Damage Control Conference 4: 105-108.

Tucker, C. S., J. A. Avery and D. Heikes. 2004. Culture methods. Pages 166-195 in Biology and culture of channel catfish. Developments in Aquaculture and Fisheries Science-34 (C. S. Tucker and J. A. Hargreaves, Eds.). Elsevier, Amsterdam, Netherlands. 
U.S. Department of Agriculture. 2008. Catfish Production. <http://usda.mannlib.cornell.edu/usda/current/CatfProd/CatfProd-07-25-2008.pdf $>$. Accessed 25 September 2008.

Weseloh, D. V. and P. J. Ewins. 1994. Characteristics of a rapidly increasing colony of Double-crested Cormorants (Phalacrocorax auritus) in Lake Ontario: popu- lation size, reproductive parameters, and band recoveries. Journal of Great Lakes Research 20: 443456.

Wywialowski, A. P. 1999. Wildlife-caused losses for producers of Channel Catfish (Italurus punctatus) in 1996. Journal of the World Aquaculture Society 30: 461-472. 